\title{
Strategies and Marketing Situation on Agricultural products in Western China ---Based on Coffee beans in Yunnan
}

\author{
Jiyan XU \\ College of Mathematics and Information, China West Normal University, Nanchong Sichuan, China. \\ Siny99_cq@sohu.com
}

Keywords: Yunnan, coffee beans, unsalable, planting area, quality, strategies

\begin{abstract}
In 2012, the sale of coffee bean was not very good in Yunnan of China. The purchase price has been declining, and there have been poor sales in some places. The main reasons are expanding of planting area, reduced quality of coffee beans, inadequate processing, and inaccurate market expectation of growers and so on. For coffee beans industry in Yunnan, we should optimize planting layout, control proper planting area, and make efforts to improve the quality of coffee beans. In addition, we can develop deep processing industries, strengthen international cooperation, and expand sales channels.
\end{abstract}

\section{Introduction}

Coffee bean is a kind of agricultural products. It is the nutlet of coffee tree fruit, which can be made into coffee after being roasted and grinded. Coffee is one of three largest non-alcoholic beverages in the world; it has some beneficial health effects, so many people like it, especially in Europe and the United States. Coffee is very popular, and then coffee bean plant is worth paying attention to. Main countries of coffee beans planting are Brazil, Colombia, Viet Nam and Mexico in the world. China also has coffee beans producing areas, which are mainly in Yunnan province and Hainan Province, Yunnan has a larger yield, and coffee in Yunnan occupies a major position in the market of china. We will investigate the coffee beans market in Yunnan province in recent years, and research marketing strategies of Yunnan coffee beans.

\section{Marketing Situation on Yunnan Coffee Beans}

Yunnan province is located in the Southwest of China. It has suitable growth condition for many agricultural crops, such as tea, tobacco, herbs, wild mushroom and fresh flowers. Because of geography and climate in Yunnan, the conditions are suitable for planting coffee beans, the main producing areas are Pu'er, Baoshan, Dehong region and Red River-producing region. Yunnan coffee beans are exported to Germany, the United Kingdom, Italy, the United States, South Korea, Japan and other countries. The main supplied companies are the top five coffee giants in the world, such as Nestlé, Maxwell companies, United States Kraft Foods, Germany Newman and Denmark Catherine IKAM.

In recent years, some diversification has taken place in Yunnan coffee beans market, Coffee beans sales price started to rise from 2010, it reached the highest level in 2011, but declined in 2012. In January 2010, the coffee beans price was 18 Yuan per kg or so, around March 2010 the price was 23 Yuan per kg, in October 2010 the price was 28 Yuan per kg or so. In January 2011 the price raised to 31 Yuan per kg, in February 2011 it reached 34.5 Yuan per kg, and later the price rose to 41 Yuan per kg. It was different in 2012, the price has been declining from 31 Yuan per kg to 20 Yuan per kilogram since March 2012, in November 2012 Nestlé acquired Arabica coffee beans in Yunnan, and the price given is 17.9 Yuan per $\mathrm{kg}$. Some local coffee beans also were unsalable, for example in coffee commune of Man former tea plantation of Pu'er city and in Empty hiromura of Mans Width township of Long yang district of Baoshan city, in which coffee farmers could only worry about the fresh fruits which have been dried. The purchase price given by Nestlé in Yunnan is based on New York Coffee futures prices which offer price 2 times each week, the price is also very transparent. The data on price diversification of coffee beans are given below in recent years: 
Table 1

The Prices of New York Coffee Beans

Futures from 2010 to 2012 (Unit: Usd/ lb)

\begin{tabular}{|l|c|r|r|}
\hline Time/Year & 2010 & 2011 & 2012 \\
& & & \\
\hline January 30 & 1.3960 & 2.3710 & 2.1660 \\
\hline February 27 & 1.3475 & 2.7165 & 2.0460 \\
\hline March 26 & 1.330 & 2.7575 & 1.7880 \\
\hline April 23 & 1.2900 & 2.8490 & 1.7895 \\
\hline May 21 & 1.3455 & 2.6400 & 1.7515 \\
\hline June 20 & 1.5095 & 2.4355 & 1.7302 \\
\hline July 25 & 1.6200 & 2.5620 & 1.7213 \\
\hline August 22 & 1.7830 & 2.2260 & 1.7165 \\
\hline September19 & 1.8750 & 2.4150 & 1.6246 \\
\hline October 24 & 1.8510 & 2.3800 & 1.5150 \\
\hline November28 & 2.0670 & 2.3160 & 1.4082 \\
\hline December17 & 2.1720 & 2.2700 & 1.4595 \\
& & & \\
\hline
\end{tabular}

Table 2

The quoted Prices of Coffee Beans

Origin in Yunnan Baoshan (Unit: Yuan/ kg)

\begin{tabular}{|l|l|l|l|}
\hline Time/Year & 2010 & 2011 & 2012 \\
\hline January 31 & 20.12 & 33.28 & 29.12 \\
\hline February28 & 19.39 & 38.20 & 27.38 \\
\hline March 27 & 19.13 & 38.75 & 23.76 \\
\hline April 24 & 18.53 & 39.87 & 23.82 \\
\hline May 22 & 18.87 & 36.84 & 23.35 \\
\hline June 21 & 21.35 & 33.70 & 23.08 \\
\hline July 26 & 22.83 & 35.40 & 22.02 \\
\hline August 23 & 25.37 & 30.38 & 21.15 \\
\hline September20 & 26.53 & 32.96 & 20.05 \\
\hline October 25 & 25.79 & 32.32 & 19.35 \\
\hline November29 & 28.89 & 31.44 & 18.02 \\
\hline
\end{tabular}

Now the eventually break-even point of Yunnan coffee beans is probably about 15 16 Yuan per $\mathrm{kg}$. Undeniably, the price of 17.9 Yuan per $\mathrm{kg}$ has started approaching the break-even point of coffee beans. If planting costs takeover bid looming, coffee farmers will be difficult to survive, seriously people may cut down coffee trees to grow other cash crops, it will affect the healthy development of coffee industry in Yunnan.

\section{Unsalable Reasons of Yunnan Coffee Beans}

\section{A. Expanding on planting area}

It is worth noting, the coffee planting area in Yunnan province is expanding. In 2008 coffee planting area in Yunnan province was 390,000 acres, in 2010 it was 439,000 acres, in 2012 it was up to 1.3 million acres, Yunnan coffee planting area grew by twice in 4 years from 2008 to 2012. On the total production, it was 28,000 tons in 2008; it was 38,000 tons in 2010; and in 2012 the number was 82,000 tons. They have been showing a trend of rapid development.

\section{B. International factors affecting}

The negative impact of America subprime mortgage crisis for the global economy has not eliminated the debt crisis in Europe appeared, and delayed in the settlement. Price initiative is in the America coffee beans futures market. The price of Yunnan coffee beans changes along with the changing in the price of coffee futures trading in the United States. New York Coffee futures price broke through the level of 200 cents per pound in October 2010, and New York Coffee futures price was about 2.38 dollars per pound in August 2011, and the price of coffee futures contract in the NYMEX New York Mercantile Exchange was about 1.71 dollars per pound in October 2012.Coffee futures suffered from the downgraded credit rating of America by the S\&P, investors sole off Coffee futures because of worrying about extending on time of global economic slowdown, and which caused falling. Coffee beans price in China just follow by the United States Coffee futures price, so it fell in 2012 in China.

\section{Declined quality of coffee beans}

Speculators crazily buy them when coffee beans price rises, then coffee beans are picked earlier by farmers, they are not yet mature, and storage condition does not meet the standards, all these factors lead to lower quality of coffee beans. At the same time the processing technologies are not very good, and dry ground is inadequate, all these reasons lead to the declining in product quality and influenced the acquisition. Furthermore, the global market of Coffee beans was bad in 2012, so the Coffee beans sales have been difficulty in Yunnan province in 2012. 


\section{Strategies Analysis on Yunnan Coffee Beans Marketing}

\section{A. Optimizing plant layout, controlling proper planting area}

Coffee beans production bases are mainly located in southeastern Yunnan, southwestern Yunnan, and southern Yunnan and in dry-hot valley region, which are the most appropriate places to plant coffee beans. We should steady and develop those suitable areas, eliminate those unsuitable areas gradually, and make bases transfer from dispersion to scale. People should control proper planting area with domestic and international market situation, according to avoid blind expansion. We can learn the successful experience from Baoshan Shennong Company and Red Hill coffee company, we must make effort to increase product quality and economic benefit of planting, and achieve the goal of increasing income for farmers.

\section{B. Improving quality of coffee beans}

The market position of coffee in Yunnan province should be identified as "Yunnan Coffee", it remains strong but not bitter, fragrant but not intense, and line into a certain image of unique quality which slightly contains fruity. In the minds of consumers around the world, it must establish a leading industrial base of high quality coffee. It's necessary to devote major efforts to develop production of non-pollution coffee and organic coffee, find research institute for technical support, innovative model of composite techniques, promote the construction of quality certification and monitoring system, comprehensively improve the quality of coffee export and improve its market competitiveness at home or abroad. Another important measure is developing high altitude coffee bean. According to studies, the physical character of coffee bean cultivated in Yunnan 1200 1500 meters above sea level is better, as well as its cup quality.

\section{Developing deep processing industry}

At present, most of coffee industries in Yunnan sell coffee mainly in the form of raw materials, the processing industry has great potential, so the government should nurture and strengthen a number of leading enterprises, facilitate their formalization, promote the development of group, and increase industry concentration. In addition, the government should give privileges from land, loans, tax and other aspects to preferential processing enterprises, promote the rapid scale and grade, and enhance their radiation and driving ability. At the same time, the government should promote the development of coffee processing business, make its brand products and brand-name products, and raise the added value of terminal coffee products as much as possible.

\section{Strengthening international cooperation and expanding sales channels}

We should further increase efforts to open up international market development of coffee products, including European and American markets and the markets of other Asian countries, so as to expand our sales channels. Government can give leading enterprises subsidy from Yunnan Province Foreign Trade Development fund or the "Science and technology" trade funds, and set up sales offices in main coffee distribution centers in Europe such as Germany and the United Kingdom, as well as in the major consuming countries of Japan and Korea in Asia. It will pave way for business, lay foundations for Yunnan coffee industry and establish international market.

\section{Acknowledgment}

This article is the phased result of School Fund Research Projects in China West Normal University; the project number is 12A031, thanks for support.

\section{References}

[1] Li Rongfu, Li Yanan, Luo Kun. Analysis on the present situation and development strategy of coffee industry in Yunnan [J]. Management of Agricultural Science and Technology. October, 2011, pp.71-74.

[2] Li Weirui, Zhou Sizheng.Development Status and Prospects of Coffee Industry in China [J]. Chinese Journal of Tropical Agriculture. October, 2011.

[3] Shui Mu. Strategy on coffee industry chain development in Yunnan [J].Practical technology in rural areas. October, 2012.

[4] Yang Ruijuan, Yunnan minor grain of coffee development present situation and prospect [J]. Practical technology in rural areas. October, 2012. 
[5] Yang Ruijuan, Yunnan minor grain of coffee development present situation and prospect [J]. Practical technology in rural areas. October, 2012. 